\title{
Access the latest
}

scholarship in political science.

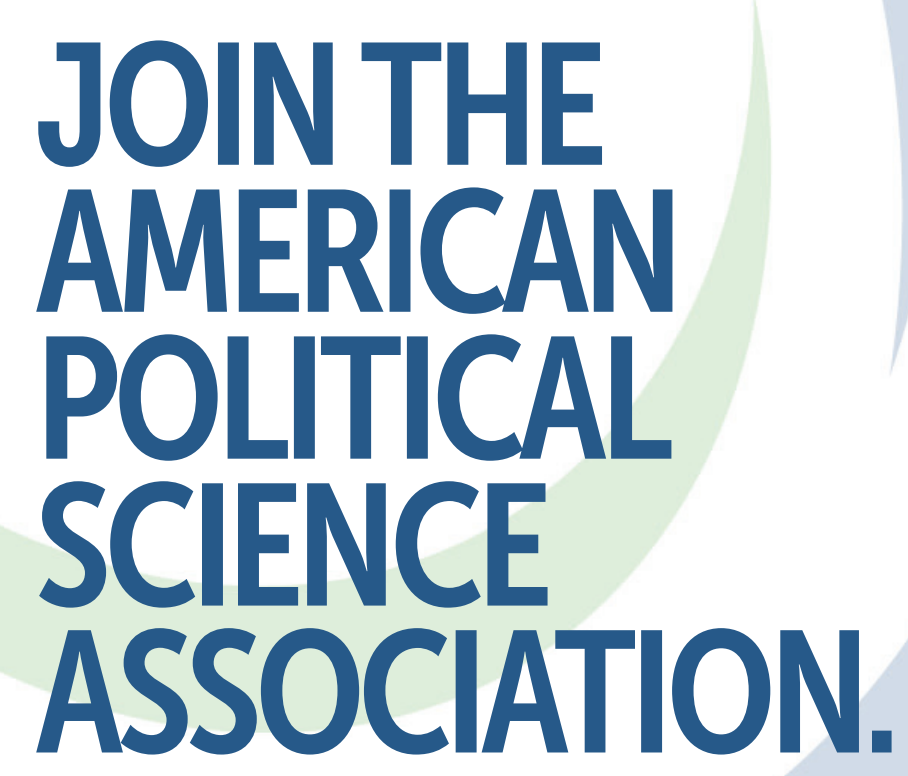

Advance your career with APSA scholarly teaching resources $\&$ opportunities.

Learn more aboutAPSA programs, grants, awards, etc.

Find jobs, postyour CV and access APSA career services.

Network with more than 6,000+ political scientists at the Annual Meeting!
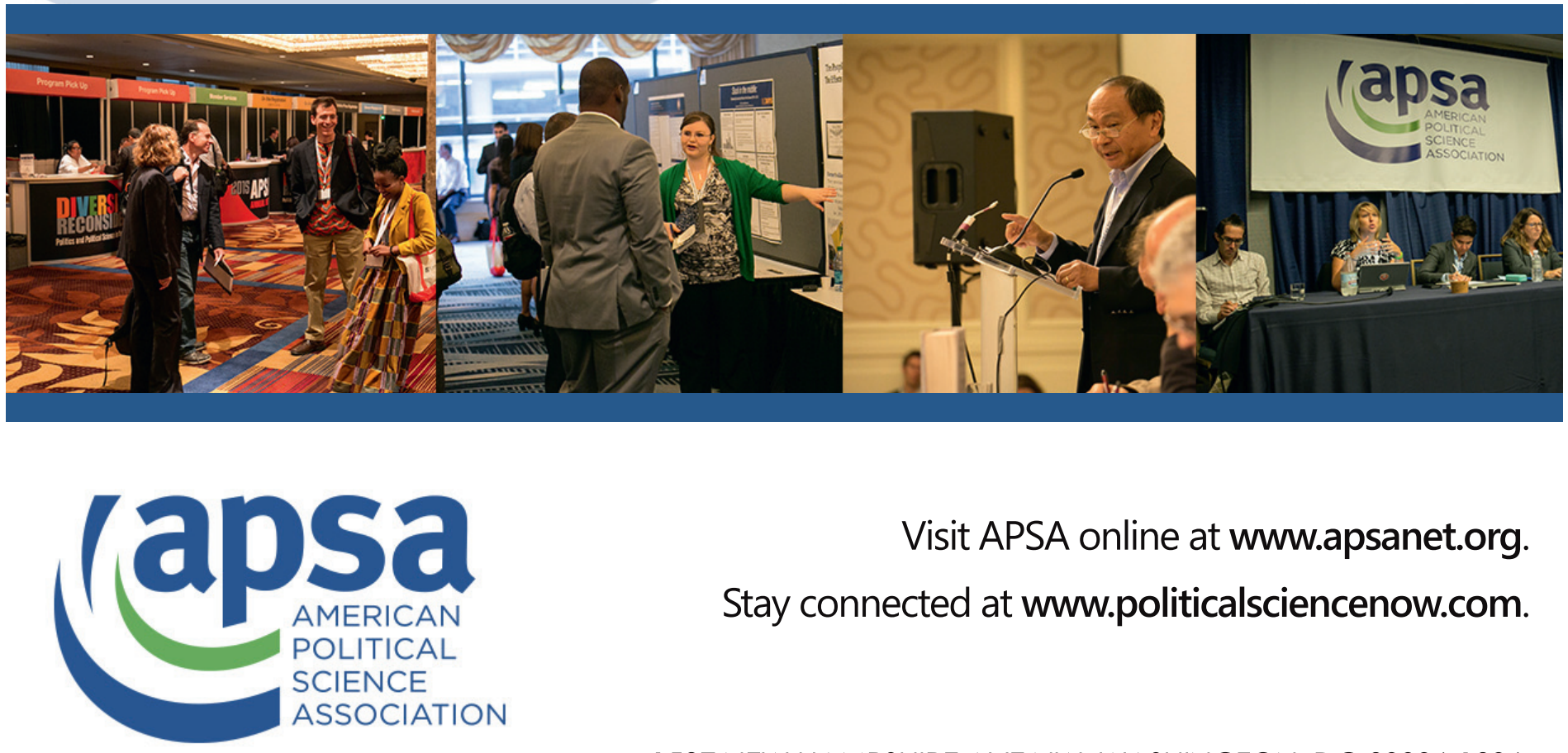

Visit APSA online at www.apsanet.org. Stay connected at www.politicalsciencenow.com. 


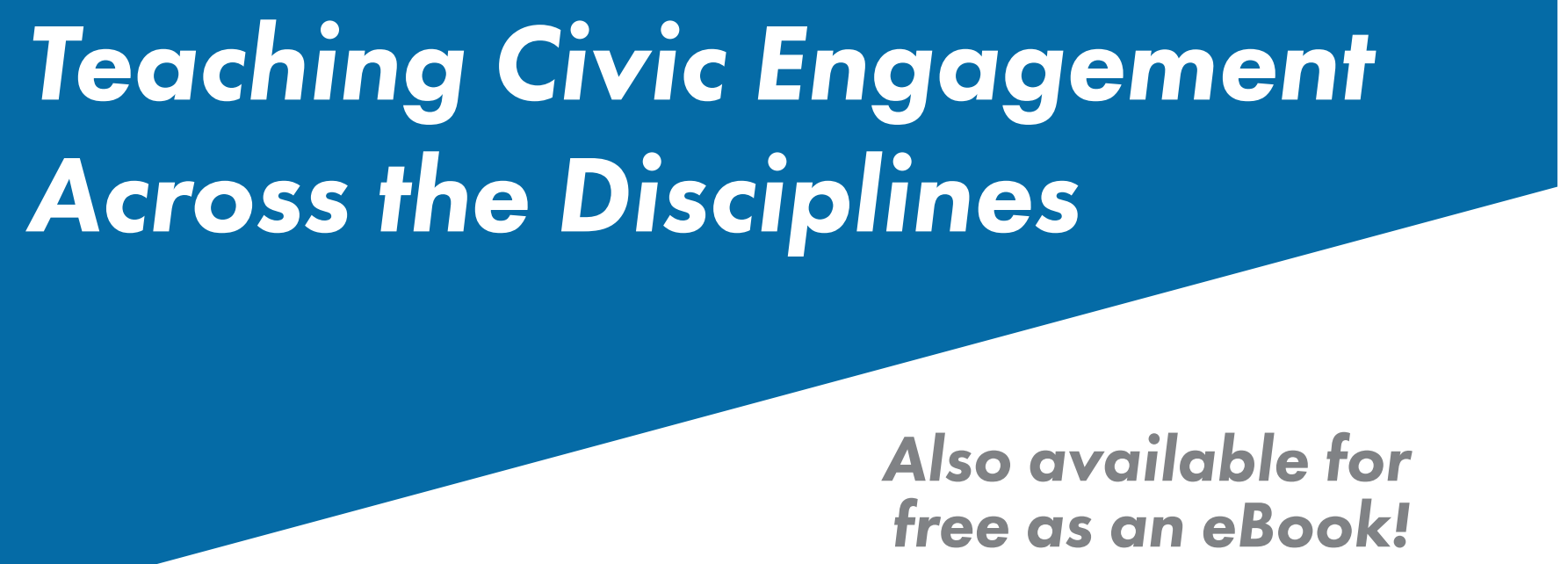

A new wave of civic instruction is moving through American education. As numerous national groups and institutions are joining this effort, political science is uniquely equipped to advance the teaching of civic engagement. The discipline should lead the movement for high quality civic education across the curriculum and across the disciplines.

To focus on this wave of civic engagement education, APSA is publishing the book Teaching Civic Engagement Across the Disciplines, edited by Elizabeth C. Matto, Rutgers University; Alison Rios Millett McCartney, Towson University; Elizabeth A. Bennion, Indiana University; and Dick Simpson, University of Illinois at Chicago.

The book redirects the focus from teaching better political science courses to teaching civic engagement across the disciplines. This movement involves university-wide coordinated civic engagement programs and action plans as well as a new nationwide action plan across high schools, community colleges, four-year colleges, and research universities to consolidate the gains that have been made and provide resources for the next leap forward. Building on the 2013 book Teaching Civic Engagement: From Student to Active Citizen, this book advances the conversation on civic engagement and provides critical scholarly insight into where to go next.

Available for purchase on Amazon! Visit www.apsanet.org/tce2.

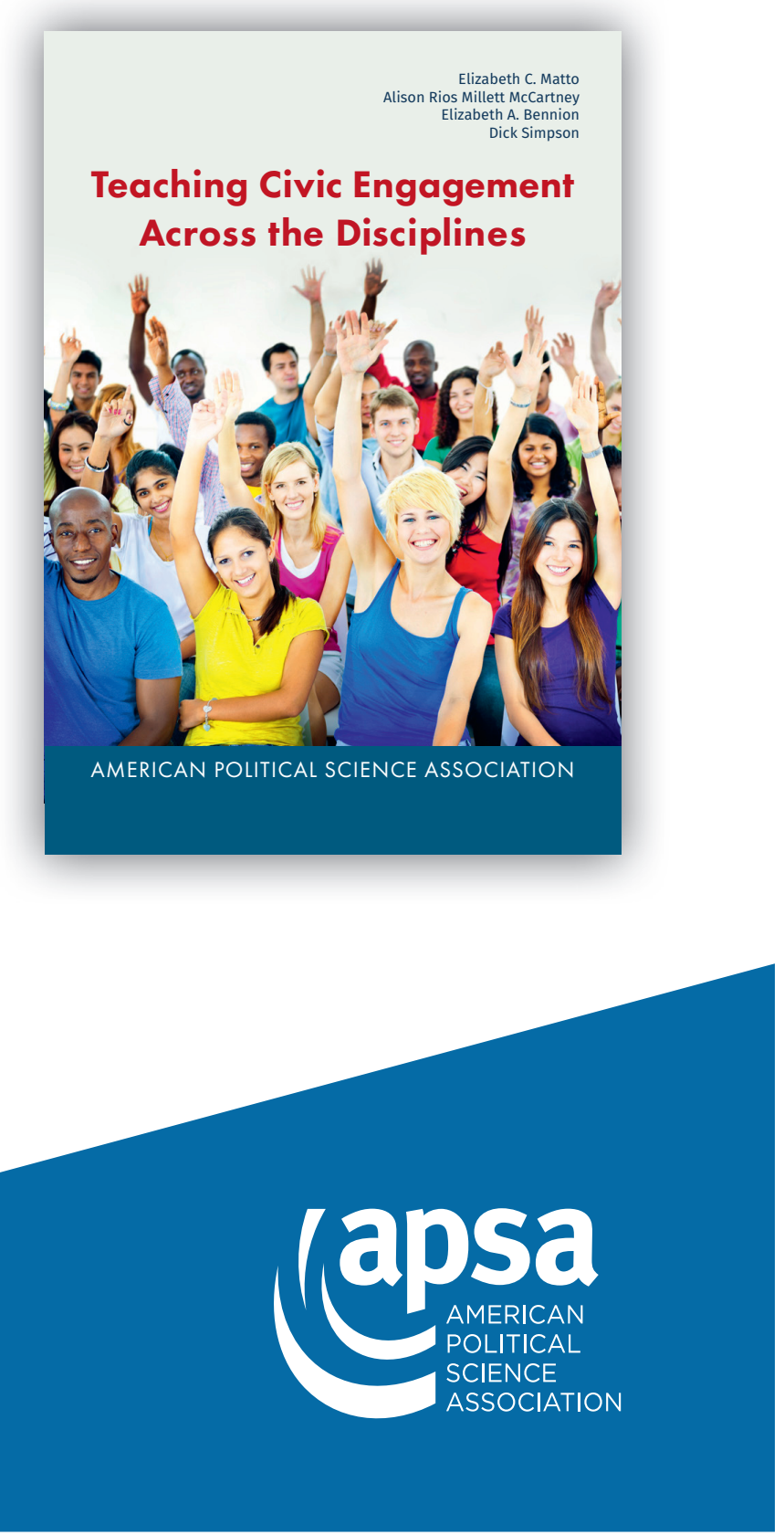




\section{Achieving Diversity and Inclusion in Political Science}

\section{Diversity and Inclusion Programs}

The American Political Science Association has several major programs aimed at enhancing diversity within the discipline and identifying and aiding students and faculty from underrepresented backgrounds in the political science field. These programs include:

Ralph Bunche Summer Institute (RBSI) (Undergraduate Juniors)

The RBSI Program is an annual five-week program designed to introduce to the world of doctoral study in political science to those undergraduate students from under-represented racial/ethnic groups or those interested in broadening participation in political science and pursuing scholarship on issues affecting underrepresented groups or issues of tribal sovereignty and governance. Application deadline: January of each year. For more information, visit www.apsanet.org/rbsi.

APSA Minority Fellows Program (MFP) (Undergraduate Seniors or MA and PhD students) (Fall Cycle for seniors and MA Students, Spring Cycle for PhD students) MFP is a fellowship competition for those applying to graduate school, designed to increase the number of individuals from under-represented backgrounds with PhD's in political science. Application deadline: October and March of each year. For more information, visit www.apsanet.org/mfp.

Minority Student Recruitment Program (MSRP) (Undergraduates and Departmental members) The MSRP was created to identify undergraduate students from under-represented backgrounds who are interested in, or show potential for, graduate study and, ultimately, to help further diversify the political science profession. For more information, visit www.apsanet.org/msrp.

\section{APSA Mentoring Program}

The Mentoring Program connects undergraduate, graduate students, and junior faculty to experienced and senior members of the profession for professional development mentoring. APSA membership is required for mentors. To request a mentor or be a mentor, visit www.apsanet.org/mentor.

\section{APSA Status Committees}

APSA Status Committees develop and promote agendas and activities concerning the professional development and current status of under-represented communities within the political science discipline. For a listing of all APSA status committees, visit www.apsanet.org/status-committees.

For more information on all Diversity and Inclusion Programs, visit us online at www.apsanet.org/ diversityprograms. Please contact Kimberly Mealy, PhD, Senior Director of Diversity and Inclusion Programs with any questions: kmealy@apsanet.org.

To contribute to an APSA Fund, such as the Ralph Bunche Endowment Fund or the Hanes Walton Jr. Fund, visit us at www.apsanet.org/donate. 
1. Publication Title

PS: Political Science \& Politics

4. Issue Frequency

Every 3 months Jan, Apr, Jul, Oct

\begin{tabular}{|c|c|}
\hline 2. Publication Number & 3. Filing Date \\
\hline $417-080$ & $10 / 01 / 2018$ \\
\hline $\begin{array}{l}\text { 5. Number of Issues Published Annually } \\
4\end{array}$ & $\begin{array}{l}\text { 6. Annual Subscription Price } \\
\$ 1903\end{array}$ \\
\hline \multirow[t]{2}{*}{ et, city, county, state, and ZIP+4() } & $\begin{array}{l}\text { Contact Person } \\
\text { Nina lammatteo }\end{array}$ \\
\hline & $\begin{array}{l}\text { Telephone (Include area code) } \\
2123375004\end{array}$ \\
\hline
\end{tabular}

7. Complete Mailing Address of Known Office of Publication (Not printer) (Street, city, county, state, and ZIP+4®)

Cambridge University Press

1 Liberty Plaza

New York, NY 10006

8. Complete Mailing Address of Headquarters or General Business Office of Publisher (Not printer)

Cambridge University Press

Edinburgh Building, Cambridge CB2 2RU, England

9. Full Names and Complete Mailing Addresses of Publisher, Editor, and Managing Editor (Do not leave blank)

Publisher (Name and complete mailing address)

Cambridge University Press

1 Liberty Plaza

New York, NY 10006

Editor (Name and complete mailing address)

Phillip Ardoin, Appalachian State University, USA

Paul Gronke, Reed College, USA

Managing Editor (Name and complete mailing address)

Celina Szymanski, American Political Science Association, USA

10. Owner (Do not leave blank. If the publication is owned by a corporation, give the name and address of the corporation immediately followed by the names and addresses of all stockholders owning or holding 1 percent or more of the total amount of stock. If not owned by a corporation, give the names and addresses of the individual owners. If owned by a partnership or other unincorporated firm, give its name and address as well as those of each individual owner. If the publication is published by a nonprofit organization, give its name and address.)

\begin{tabular}{l|l}
\hline Full Name & Complete Mailing Address \\
\hline & \\
\hline & \\
\hline & \\
\hline
\end{tabular}

11. Known Bondholders, Mortgagees, and Other Security Holders Owning or Holding 1 Percent or More of Total Amount of Bonds, Mortgages, or Other Securities. If none, check box $\rightarrow$ None

\begin{tabular}{l|l}
\hline Full Name & Complete Mailing Address \\
\hline & \\
\hline & \\
\hline & \\
\hline
\end{tabular}

12. Tax Status (For completion by nonprofit organizations authorized to mail at nonprofit rates) (Check one)

The purpose, function, and nonprofit status of this organization and the exempt status for federal income tax purposes:

$\square$ Has Not Changed During Preceding 12 Months

$\square$ Has Changed During Preceding 12 Months (Publisher must submit explanation of change with this statement) 


\begin{tabular}{|c|c|c|c|c|}
\hline \multirow{2}{*}{\multicolumn{3}{|c|}{$\begin{array}{l}\text { 13. Publication Title } \\
\text { PS: Political Science \& Politics } \\
\text { 15. Extent and Nature of Circulation }\end{array}$}} & \multicolumn{2}{|c|}{$\begin{array}{l}\text { 14. Issue Date for Circulation Data Below } \\
\text { JULY } 2018\end{array}$} \\
\hline & & & \multirow{2}{*}{\begin{tabular}{|c|}
$\begin{array}{l}\text { Average No. Copies } \\
\text { Each Issue During } \\
\text { Preceding } 12 \text { Months }\end{array}$ \\
4131 \\
\end{tabular}} & $\begin{array}{l}\text { No. Copies of Single } \\
\text { Issue Published } \\
\text { Nearest to Filing Date }\end{array}$ \\
\hline \multicolumn{3}{|c|}{ a. Total Number of Copies (Net press run) } & & 4080 \\
\hline \multirow{4}{*}{$\begin{array}{l}\text { b. Paid } \\
\text { Circulation } \\
\text { (By Mail } \\
\text { and } \\
\text { Outside } \\
\text { the Mail) }\end{array}$} & (1) & $\begin{array}{l}\text { Mailed Outside-County Paid Subscriptions Stated on PS Form } 3541 \text { (Include paid } \\
\text { distribution above nominal rate, advertiser's proof copies, and exchange copies) }\end{array}$ & 2644 & 2508 \\
\hline & (2) & $\begin{array}{l}\text { Mailed In-County Paid Subscriptions Stated on PS Form } 3541 \text { (Include paid } \\
\text { distribution above nominal rate, advertiser's proof copies, and exchange copies) }\end{array}$ & 0 & 0 \\
\hline & (3) & $\begin{array}{l}\text { Paid Distribution Outside the Mails Including Sales Through Dealers and Carriers, } \\
\text { Street Vendors, Counter Sales, and Other Paid Distribution Outside USPS }\end{array}$ & 847 & 842 \\
\hline & (4) & $\begin{array}{l}\text { Paid Distribution by Other Classes of Mail Through the USPS } \\
\left.\text { (e.g., First-Class Mail( }{ }^{\Theta}\right)\end{array}$ & 0 & 0 \\
\hline \multicolumn{3}{|c|}{ c. Total Paid Distribution [Sum of 15b (1), (2), (3), and (4)] } & 3491 & 3350 \\
\hline \multirow{4}{*}{$\begin{array}{l}\text { d. Free or } \\
\text { Nominal } \\
\text { Rate } \\
\text { Distribution } \\
\text { (By Mail } \\
\text { and } \\
\text { Outside } \\
\text { the Mail) }\end{array}$} & (1) & Free or Nominal Rate Outside-County Copies included on PS Form 3541 & 0 & 0 \\
\hline & (2) & Free or Nominal Rate In-County Copies Included on PS Form 3541 & 0 & 0 \\
\hline & (3) & $\begin{array}{l}\text { Free or Nominal Rate Copies Mailed at Other Classes Through the USPS } \\
\text { (e.g., First-Class Mail) }\end{array}$ & 0 & 0 \\
\hline & (4) & Free or Nominal Rate Distribution Outside the Mail (Carriers or other means) & 12 & 7 \\
\hline \multicolumn{3}{|c|}{ e. Total Free or Nominal Rate Distribution (Sum of 15d (1), (2), (3) and (4)) } & 12 & 7 \\
\hline \multicolumn{3}{|c|}{ f. Total Distribution (Sum of $15 \mathrm{c}$ and $15 \mathrm{e}$ ) } & 3503 & 3357 \\
\hline \multicolumn{3}{|c|}{ g. Copies not Distributed (See Instructions to Publishers \#4 (page \#3)) } & 327 & 723 \\
\hline \multicolumn{3}{|c|}{ h. Total (Sum of $15 f$ and $g$ ) } & 3830 & 4080 \\
\hline \multicolumn{3}{|c|}{$\begin{array}{l}\text { i. Percent Paid } \\
(15 \mathrm{c} \text { divided by } 15 \mathrm{f} \text { times } 100)\end{array}$} & $99.66 \%$ & $99.79 \%$ \\
\hline
\end{tabular}

* If you are claiming electronic copies, go to line 16 on page 3 . If you are not claiming electronic copies, skip to line 17 on page 3 .

PS Form 3526, July 2014 (Page 2 of 4)

UNITED STATES

Statement of Ownership, Management, and Circulation POSTAL SERVICE $\otimes$ (All Periodicals Publications Except Requester Publications)

\begin{tabular}{l|c|c}
\hline 16. Electronic Copy Circulation & $\begin{array}{l}\text { Average No. Copies } \\
\text { Each Issue During } \\
\text { Preceding 12 Months }\end{array}$ & $\begin{array}{l}\text { No. Copies of Single } \\
\text { Issue Published } \\
\text { Nearest to Filing Date }\end{array}$ \\
\hline \begin{tabular}{l} 
a. Paid Electronic Copies \\
\hline b. Total Paid Print Copies (Line 15c) + Paid Electronic Copies (Line 16a)
\end{tabular} & 0 \\
\hline $\begin{array}{l}\text { c. Total Print Distribution (Line 15f) + Paid Electronic Copies (Line 16a) } \\
\text { d. Percent Paid (Both Print \& Electronic Copies) (16b divided by 16c } \times 100)\end{array}$ & 3491 & 3350 \\
\hline
\end{tabular}

QI certify that $50 \%$ of all my distributed copies (electronic and print) are paid above a nominal price.

17. Publication of Statement of Ownership

$\square$ If the publication is a general publication, publication of this statement is required. Will be printed

$\square$ Publication not required. in the issue of this publication.

18. Signature and Title of Editor, Publisher, Business Manager, or Owner
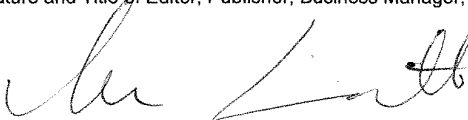

Date

$10 / 01 / 2018$

certify that all information furnished on this form is true and complete. I understand that anyone who furnishes false or misleading information on this form or who omits material or information requested on the form may be subject to criminal sanctions (including fines and imprisonment) and/or civil sanctions (including civil penalties) 


\section{Navigating Political Science}

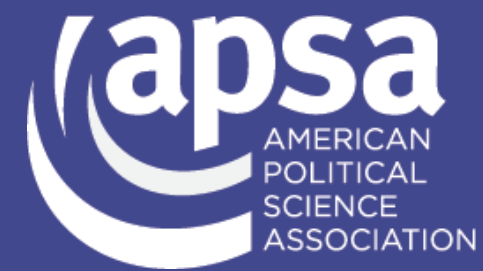

Navigating the political science discipline can be a daunting task for those unfamiliar with its nuances. APSA's newest resource offers advice on handling the challenges presented by the discipline and taking full advantage of its opportunities.

Navigating Political Science:ProfessionalAdvancement $\mathcal{E}$ Success in the Discipline, edited by Kent Worcester, brings together some of the most noteworthy, discipline-focused contributions to APSA journals published over the past couple of decades. With 28 chapters by 45 contributors, the book touches on topics that range from peer review, mentoring, and faculty governance, to blogging, data collection, and digital media in the classroom. The book should prove relevant for political scientists across the board, from aspiring ABDs to seasoned PhDs.

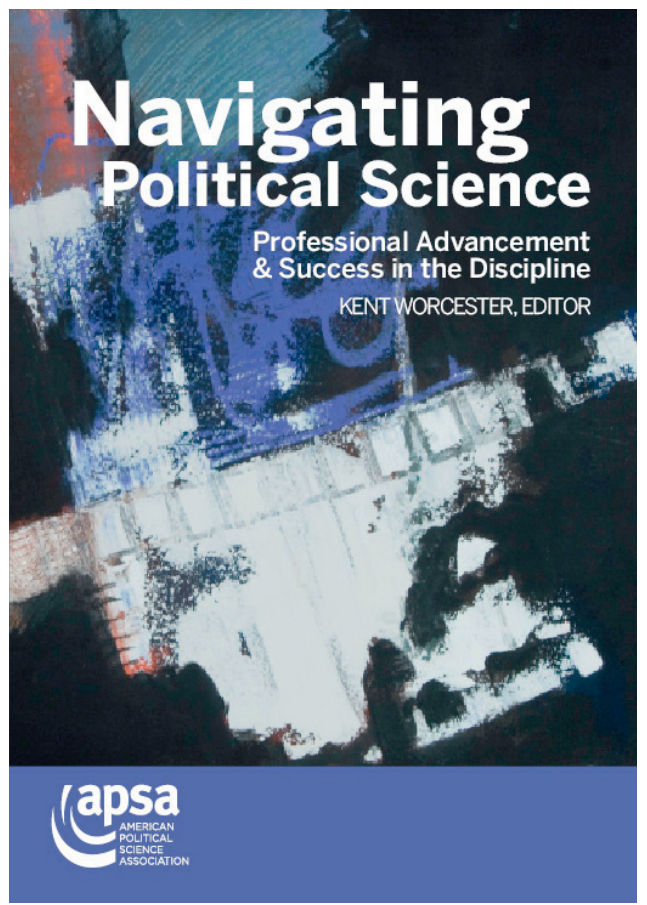

\section{Read the free PDF available online!}

\section{Scan to learn more or visit www.apsanet.org/navigating}

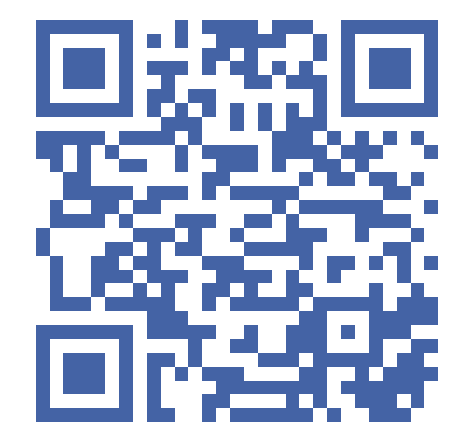




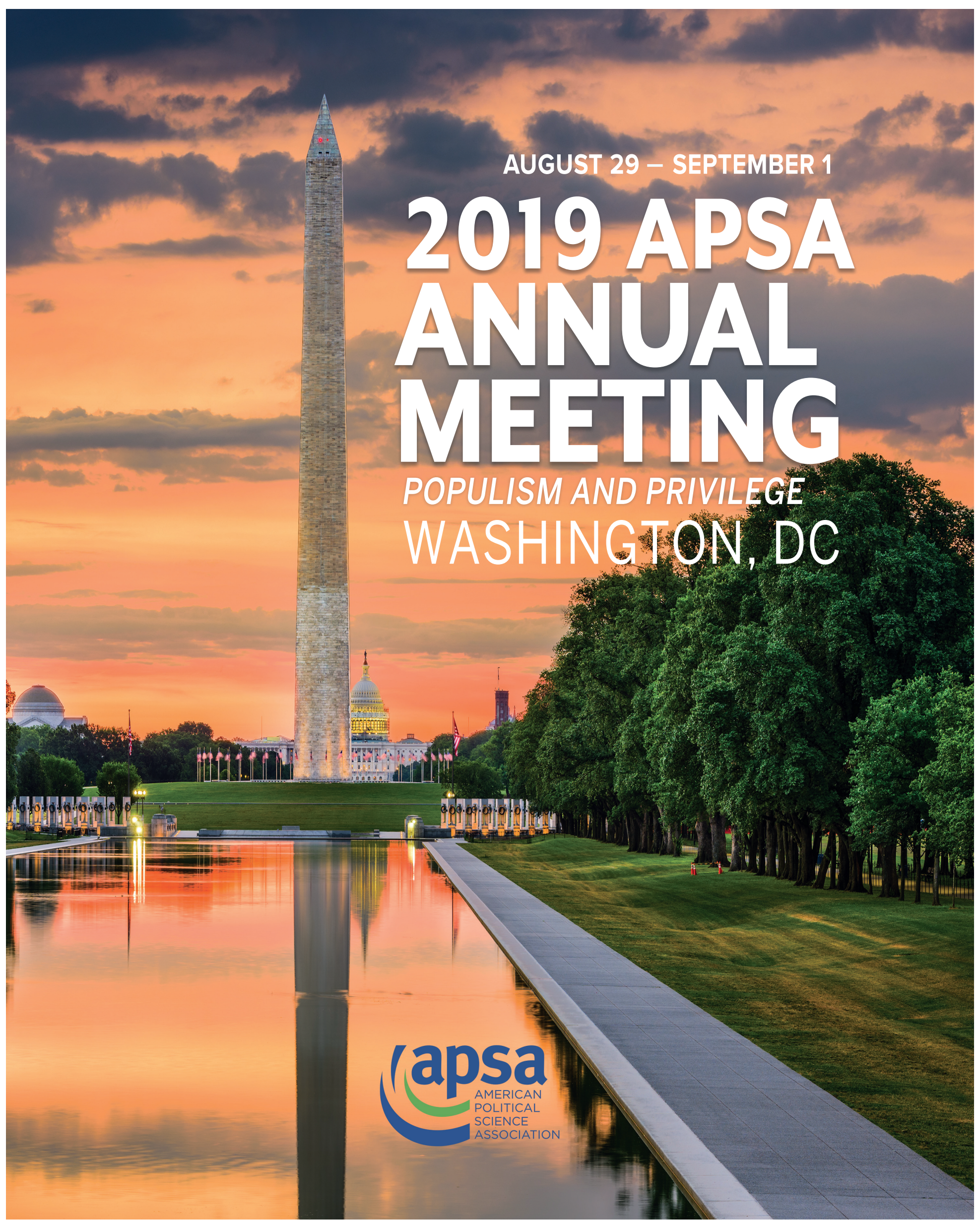

\section{Cambridge Core}

For further information about this journal please go to the journal website at:

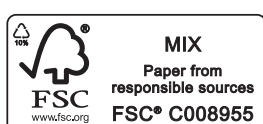

CAMBRIDGE UNIVERSITY PRESS 